\title{
Introduction: The Little Ice Age and the General Crisis
}

In 1638, from the safety of his Oxford College, Robert Burton informed readers of his best-selling book, The anatomy of melancholy, that 'every day' he received news of

\begin{abstract}
war, plagues, fires, inundations, thefts, murders, massacres, meteors, comets, spectrums, prodigies, apparitions; of towns taken, cities besieged in France, Germany, Turky, Persia, Poland, \&c.; daily musters and preparations, and such like, which these tempestuous times affoord; battels fought, so many men slain, monomachies [regicides], shipwracks and sea-fights, peace, leagues, stratagems, and fresh alarums.
\end{abstract}

Six years later, a group of London merchants lamented that 'All trade and commerce in this kingdom is almost fallen to the ground through our own unhappy divisions at home', namely the English Civil War, 'and as the badness of trade and scarcity of money are here, so is all Europe in little better condition, but in a turmoil [of] either foreign or domestic war.' In 1643 the preacher Jeremiah Whitaker warned that '[These] days are days of shaking, and this shaking is universal: the Palatinate, Bohemia, Germany, Catalonia, Portugal, Ireland, England.' Normally, Whitaker argued, God 'shakes all successively', but now it seemed that He planned to 'shake all nations collectively, jointly and universally'. So much simultaneous 'shaking', he concluded, must herald the Day of Judgment. ${ }^{1}$

That same year, in Spain, a tract entitled Nicandro [The victor] made the same point.

Sometimes Providence condemns the world with universal and evident calamities, whose causes we cannot know. This seems to be one of the epochs in which every nation is turned upside down, leading some great minds to suspect that we are approaching the end of the world. We have seen all the north in commotion and rebellion, its rivers running with blood, its populous provinces deserted; England, Ireland and Scotland aflame with Civil War.

'What area does not suffer', the Nicandro asked rhetorically: 'if not from war, then from earthquakes, plague and famine?'2 
In Germany, a Swedish diplomat expressed alarm in 1648 at a new bout 'of revolts by the people against their rulers everywhere in the world, for example in France, England, Germany, Poland, Muscovy, the Ottoman empire. He was well informed: civil war had just begun in France and continued to rage in England; the Thirty Years' War (1618-48) had left much of Germany devastated and depopulated; the Cossacks of Ukraine had just rebelled against their Polish overlords and massacred thousands of Jews; revolts rocked Moscow and other Russian cities; and an uprising in Istanbul led to the murder of the Ottoman sultan. The following year, in Paris, a Scottish exile concluded that he and his contemporaries lived in an 'Iron Age' that would become 'famous for the great and strange revolutions that have happened in it'. In 1653, in Brussels, historian JeanNicolas de Parival informed his readers that 'I call this century the "Iron Century" ' because so many misfortunes 'have come together, whereas in previous centuries they came one by one. Rebellions and wars, he continued, now 'resemble Hydra: the more you cut off their heads, the more they grow'. Parival also noted that 'The Elements, servants of an irate God, combine to snuff out the rest of humankind. Mountains spew out fire, the earth shakes, plague contaminates the air', and 'the continuous rain causes rivers to flood.'

Seventeenth-century China also suffered. A combination of droughts and disastrous harvests, rising tax demands and drastic reductions in government programs unleashed a wave of banditry and chaos until in 1644 one of the bandit leaders, Li Zicheng, declared himself ruler of China and seized Beijing from the demoralized defenders of the Ming emperor (who committed suicide). Almost immediately, China's northern neighbours, the Manchus or Qing, invaded and defeated Li, entered Beijing and for the next thirty years ruthlessly extended their authority over the whole country. Several million people perished in the Ming-Qing transition; millions more lost their property and their freedom.

Few areas of the world escaped the consequences of global cooling. North America and West Africa both experienced famines and wars in the mid-seventeenth century. In Japan, following several poor harvests, in 1637-38 the largest rural rebellion in modern Japanese history occurred on the island of Kyushu. Revolution broke out in France, Sicily, Naples, Russia, Ukraine and the Ottoman empire in 1647-48, a year of extreme weather in much of the northern hemisphere. In India, a vicious war of succession in the Mughal empire from 1658 to 1662 intensified the impact of severe drought. In each case natural and human factors combined to create a comprehensive demographic, social, economic and political catastrophe that lasted for two generations.

Those who lived in the mid-seventeenth century believed that they faced unprecedented hardships, leading many of them to record their 
misfortunes as a warning to others. 'Those who live in times to come will not believe that we who are alive now have suffered such toil, pain and misery', wrote Francesco Voersio, an Italian friar, in his 'Plague Diary'; Nehemiah Wallington, a London craftsman, compiled several volumes of 'Historical notes and meditations' so that 'the generation to come may see what wofull and miserable times we lived in'; and the German Lutheran pastor Johann Daniel Minck started to keep a diary because 'without such records' he feared that 'those who come after us will never believe what miseries we have suffered'. ${ }^{4}$

In 1649, the Welsh historian James Howell speculated that:

God Almighty has a quarrel lately with all Mankind, and given the reins to the ill Spirit to compass the whole Earth; for within these twelve years there have the strangest Revolutions and horridest things happened, not only in Europe but all the world over, that have befallen mankind (I dare boldly say) since Adam fell, in so short a revolution of time ... [Such] monstrous things have happened [that] it seems the whole world is off the hinges; and (which is the more wonderful) all these prodigious passages have fallen out in less than the compass of twelve years. ${ }^{5}$

Two years later, in his book Leviathan, the English philosopher Thomas Hobbes provided perhaps the most celebrated description of the consequences of the fatal synergy between natural and human disasters that threatened him and his contemporaries:

There is no place for industry, because the fruit thereof is uncertain, and consequently no culture of the Earth; no navigation, nor use of the commodities that may be imported by sea; no commodious building; no instruments of moving and removing such things as require much force; no knowledge of the face of the Earth; no account of Time; no arts; no letters; no society. And, which is worst of all, continual fear and danger of violent death; and the life of man, solitary, poor, nasty, brutish and short. ${ }^{6}$

When did this fatal synergy commence? In 1652, the Italian historian Majolino Bisaccione traced the sequence of 'popular revolts in my lifetime' back to the rebellion of Bohemia in 1618, which attracted the support of some German Protestants, led by Frederick of the Palatinate, and thus began a civil war in Central Europe. A few years later, the English antiquarian John Rushworth agreed. When he sought to explain 'how we came to fall out among ourselves' in the English Civil War, he too started his account in 1618 because his research convinced him that the conflict originated in the 
causes and grounds of the war in the Palatinate, and how far the same concerned England, and the oppressed Protestants in Germany'. He therefore 'resolved that very instant should be the Ne Plus Ultra of my retrospect.'

The human and natural archives both vindicate this chronology. Although Europe had experienced many earlier economic, social and political crises, they remained largely isolated and relatively short-lived. By contrast, the Bohemian revolt began a conflict that lasted three decades and eventually involved all the major states of Europe: Denmark, the Dutch Republic, France, Poland, Russia, Sweden, the Swiss Confederation and the Stuart and Spanish monarchies. The year 1618 also saw a long-running crisis commence in two other parts of the world. In the Ottoman empire, a palace faction toppled the sultan (the first such event in the history of the dynasty), unleashing a series of disasters that a generation later the scholarbureaucrat Kâtib Çelebi would term Haile-i Osmaniye: 'The Ottoman Tragedy'. Meanwhile, in East Asia, Nurhaci, leader of a confederation of Manchurian tribes, declared war on the Chinese emperor and invaded Liaodong, a populous area of Chinese settlement north of the Great Wall. Some observers immediately realized the significance of this step. Years later, Wu Yingji, a gentleman-scholar, recalled 'a friend telling me, when the difficulties began in the eighth month of 1618 in Liaodong, that the state would have several decades of warfare; and my thinking that his words were absurd because the state was quite intact'. Nevertheless his friend had been right: the Manchu invasion initiated almost seven decades of warfare. ${ }^{8}$ The natural archive reveals a serious drought in many parts of sub-Saharan Africa from 1614 to 1619; heavy snowfalls in subtropical Fujian in 1618; an intensely cold winter in 1620-21 in Europe; and drought in both the Valley of Mexico and Virginia from 1616 to 1621 . In addition, 1618 marked the beginning of a prolonged aberration in the behaviour of the sun, with the gradual disappearance of sunspots, auroras borealis, and coronas. For all these reasons, I follow the lead of Bisaccione, Rushworth, Kâtib Çelebi and Wu Yingji's friend: 1618 is 'the ne plus ultra of my retrospect', the point where a fatal synergy between natural and human disasters began.

When did it end? Here the evidence is less consistent. In 1668 Hobbes began Behemoth, his account of the English Civil Wars, by observing that:

If in time, as in place, there were degrees of high and low, I verily believe that the highest of times would be that which passed between the years 1640 and 1660 . For he that thence, as from the Devil's Mountain, should have looked upon the world and observed the actions of men, especially in England, might have had a prospect of all kinds of injustice and all kinds of folly that the world could afford. ${ }^{9}$ 
Yet twenty years later another revolution occurred: William of Orange landed at the head of the largest army ever to invade first Britain and then Ireland, in both of which he created a new regime. On the European continent, the last of the disputes unleashed by the revolt of Bohemia were resolved in 1659-61, but France's invasion of the Palatinate in 1688 generated a new decade of conflict. In the Ottoman empire, the grand vizier Köprülü Mehmed Pasha managed to end the cycle of domestic rebellion in the 1650s and the empire began to expand again; but the defeat of the Turkish army before Vienna in 1683 halted the advance and produced protests and the deposition of another sultan. Elsewhere, however, several conflicts ended. In 1683, Manchu troops finally defeated the last of their opponents, allowing a government inspector to exult that the Qing emperor 'has crushed all the rebels and even the seas are calm. At present, the people have returned to their former lands. Their homes are protected and their livelihood is secure. They will respect and honour Your Majesty's benevolence for generations to come', bringing China's seventeenth-century crisis to an end at last. ${ }^{10}$ Three years later, the Eternal Peace of Moscow marked Russia's permanent ascendancy over the Polish-Lithuanian Commonwealth.

Nevertheless, the Little Ice Age continued. In the northern hemisphere, nine of the fourteen summers between 1666 and 1679 were either cool or exceptionally cool, and harvests in Western Europe ripened later in 1675 than in any other year between 1484 and 1879. Climatologists regard the 1690 s, with average temperatures $1.5^{\circ} \mathrm{C}$ below those of today, as the climax of the Little Ice Age - and yet, this time, global cooling did not produce a wave of revolutions. The fatal synergy had ended. This book seeks to explain why.

Writing global history is full of pitfalls. In 2011 Alain Hugon prefaced his admirable study of the revolt of Naples in 1647-48 with a lament that although 'contemporaries clearly stated that no barriers separated the various revolutions of the seventeenth century', they were so numerous that 'we historians of the twentieth and twenty-first centuries dare not study them in their totality, despite our awareness of this synchronicity, of the interdependence, and of the interactions that occurred. Whenever Hugon 'tried to make historical comparisons appropriate to the mid-seventeenth century', he found that 'the problems that arise from the need to contextualize each historical event render the attempt vain.' ${ }^{11}$

At first sight, this view is very persuasive: we now know about far more upheavals, many of far greater complexity, than previous scholars suspected. Hugon himself uncovered evidence of over one hundred revolts in the kingdom of Naples in 1647-48, and other researchers have revealed that almost half the towns of Portugal rebelled in 1637; over twenty Andalusian towns and cities participated in the Green Banner revolts of 1648-52; and over a million Chinese joined the bandit armies that eventually destroyed 
Ming rule. Moreover, contingency complicates the task of explaining the synchronicity, interdependence and interactions of the various revolts. Although most parts of the northern hemisphere experienced both the Little Ice Age and the General Crisis in the mid-seventeenth century, they did so in different ways, for different reasons, and with different outcomes - in part because some structural causes (such as climate change) lay largely beyond human control, while others (such as wars and revolutions) involved so many people that they lay largely beyond the control of any individual. Apparently minor events repeatedly produced consequences that were both unanticipated and disproportionate. As Dr Samuel Johnson observed in 1771:

It seems to be almost the universal error of historians to suppose it politically, as it is physically true, that every effort has a proportionate cause. In the inanimate action of matter upon matter, the motion produced can be but equal to the force of the moving power; but the operations of life, whether private or publick, admit no such laws. The caprices of voluntary agents laugh at calculation. It is not always that there is a strong reason for a great event. ${ }^{12}$

Historians must identify the precise moment in each historical process when 'the motion produced' ceased to be 'equal to the force of the moving power. To describe such moments John Lewis Gaddis adopted from physics the term 'phase transitions': the point 'where water begins to boil or freeze, for example, or sand piles begin to slide, or fault lines begin to fracture'. Malcolm Gladwell popularized the term 'tipping point' in his best-selling book of the same name - a more appropriate concept because it implies that such changes, however sudden and dramatic, may one day be reversed. Ice, after all, can easily turn back to water. The subtitle of Gladwell's book, How little things can make a big difference, is also appropriate, because the harsher environment of the seventeenth century heightened the role of chance and contingency in human affairs. When historically important outcomes depend on the actions of relatively few people amid fraught conditions, little things can easily 'make a big difference.' ${ }^{13}$

This book studies the Global Crisis of the seventeenth century through three different lenses. Part I presents data from both the human and natural archives that reveal the mechanisms through which the crisis affected humankind. Chapter 1 evaluates how global cooling affects the supply of food, especially of staple crops such as cereals, maize and rice. Chapter 2 examines how early modern states pursued policies that intensified economic hardship and enforced unpopular measures that destabilized societies already under economic stress from climate change, and (more rarely) adopted initiatives that mitigated the consequences of global cooling. 
The most intense manifestations of crisis occurred mainly in four zones: composite states, marginal lands, cities and macroregions (densely populated areas that concentrated on producing goods for export rather than for local consumption). Composite states, normally created by dynastic unions, were especially vulnerable because the ruler's authority was normally weaker in peripheral areas, yet in wartime those peripheral areas often experienced enhanced political and economic pressure, and rebelled first (Chapter 2). Marginal lands relied disproportionately on the yield of crops vulnerable to climate change. Cities and macroregions regularly suffered fiscal and military calamities because governments and armies both tended to target places that boasted a large, compact population; they also proved vulnerable to political and military changes both at home and in areas critical for their imports or exports (Chapter 3). Chapter 4 examines the demographic responses by the victims in different regions as they faced a growing imbalance between supply of and demand for resources.

Part II examines a dozen states in Eurasia that experienced the full intensity of both the Little Ice Age and the General Crisis, proceeding geographically from east to west: China; Russia and Poland; the Ottoman empire; Germany and Scandinavia; the Dutch Republic; the Iberian Peninsula; France; Great Britain and Ireland (Chapters 5-12). Each chapter charts the interplay of human and natural forces right up to the tipping point that ended the existing social, economic and political equilibrium; it then analyses the nature of the ensuing crisis; and it documents the emergence of a new equilibrium.

The choice of an east-to-west itinerary, starting with China and ending with Ireland, is arbitrary: it reflects neither chronological differences (in most cases the 'days of shaking' began in or around 1618 and ended in the 1680s) nor the intensity of the crisis (although in terms of physical and personal damage, China and Ireland seem to have suffered worst of all). By contrast, the decision to devote greater space to the experience of Britain and Ireland than to other states gripped by major trauma is deliberate: the upheavals there lasted longer and produced more dramatic changes than anywhere else except China, and the wealth of surviving sources that they generated permit a more detailed understanding of the causes, course and consequences of the crisis than is possible for any other society.

Part III considers two categories of exception to this pattern: areas where at least part of the population emerged from the seventeenth-century trauma relatively unscathed (some European colonies in America; Spanish Italy; South and Southeast Asia; Japan); and regions where the impact of the Little Ice Age remains ambiguous (the Great Plains of North America; sub-Saharan Africa; Australia). Within the first category, the abundant resources of Mughal India and some of its neighbours enabled the state to ride out the crisis (Chapter 13), and in Spanish Italy the government managed to overcome 
major rebellions by making major concessions (Chapter 14). Elsewhere, notably in Europe's overseas outposts, the prosperity of a few (the European colonists) was achieved at the expense of the many (the indigenous population: Chapter 15). Only Japan seems to have avoided the full effects of the crisis, thanks to human initiatives: although global cooling caused a major famine in the archipelago during the 1640s, a barrage of effective countermeasures first limited and then repaired the damage (Chapter 16).

Despite the diversity of human experience in the states and societies afflicted by the General Crisis, some common denominators emerge, and Part IV considers three of them. First, popular responses to catastrophe exhibited several similar protocols and conventions, ranging from a surprising measure of restraint in violent protests around the world to striking similarities in what James C. Scott termed the weapons of the weak': 'foot-dragging, dissimulation, desertion, false compliance, pilfering, feigned ignorance, slander, arson, sabotage' (Chapter 17). ${ }^{14}$ Second, an investigation of the individuals and groups in different societies who exploited the mounting instability to produce a tipping point also exposes similarities. In many areas aristocrats played a prominent role, as they had done in many earlier crises; but in the mid-seventeenth century, from China through the Muslim world to Europe, the most prominent 'troublemakers' included men (some clerical, others secular) who had made great sacrifices to acquire advanced education but then failed to find suitable employment (Chapter 18). A third common denominator is the rapid dissemination of radical ideas. Sometimes the rebels themselves spread the word. In 1647 the ease of passage of insurgents between Naples and Palermo synchronized the rebellions in the two capitals; the following year, the return from Moscow of men who had watched spellbound as rioters forced the tsar to make massive concessions triggered copycat rebellions in the provinces. Radical ideas also spread because in much of Asia and Europe the proliferation of printed works and of schools had created a literate proletariat of unprecedented size and sophistication, capable of reading, discussing and implementing new ideas. Thus although the Catholics of Ireland hated and feared the Calvinists of Scotland, they were prepared to learn from them. A few days after the 1641 uprising, when a captured Protestant asked a leading Irish Catholic if "Yow have made a Covenant amongst yow as the Scotts did?" "Yea", said hee, “The Scotts have taught us our A.B.C."' (Chapter 19). ${ }^{15}$

Part V examines how survivors coped with the aftermath of the crisis. Although the 1690s and 1700s saw further bouts of extreme weather, famine and (in Europe and China) almost continuous war, no revolutions and relatively few revolts occurred. Although the Little Ice Age continued, the General Crisis did not.

Several developments help to explain this paradox. In most parts of the globe, the experience of state breakdown and the continual fear and danger 
of violent death' cooled the general ardour for economic, political and religious change. Most subjects now favoured political stability, economic innovation and religious toleration; many governments switched at least some resources from warfare to welfare and fostered economic regeneration (Chapters 20 and 21). The final chapter examines a variety of intellectual responses devised to cope more effectively with future crises, some (like compulsory universal schooling) imposed by the state, others emerging among subjects (including 'practical knowledge' in China and Japan, the 'new reason' in Mughal India, and the 'scientific revolution' in Europe). These innovations put down deeper roots in the West than elsewhere and formed a crucial ingredient in the 'Great Divergence' that developed between East Asia and Northwest Europe.

The Conclusion considers some implications of the fact that catastrophe is not an aberration but an integral part of human history, and the Epilogue suggests that the current debate on global warming confuses two distinct issues: whether human activity is making the world warmer; and whether or not sudden climate change can occur. Although a few may still deny the first, the seventeenth-century evidence places the second beyond doubt. Since the critical issue is not whether climate change occurs, but when, the critical question is whether states and societies are willing to invest money now to prepare for future climate-induced catastrophes that are inevitable - hurricanes and typhoons of greater force; more intense heatwaves, droughts and floods; rising sea levels - or would rather wait and pay the far higher costs of inaction that are likewise inevitable. 
